Who Wants to Be a Jewish Writer? 
This page intentionally left blank 


\section{Who Wants}

\section{to Be a Jewish}

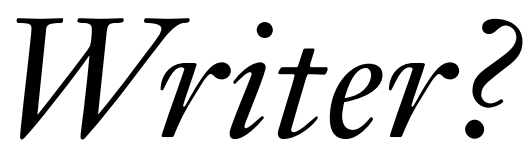

And Other Essays

\section{Adam Kirsch}

Yale UnIVERSITy PRESS

New Haven \& London 
Published with assistance from the Mary Cady Tew Memorial Fund.

Copyright (C) 2019 by Adam Kirsch.

All rights reserved.

This book may not be reproduced, in whole or in part, including illustrations, in any form (beyond that copying permitted by Sections Io7 and Io8 of the U.S. Copyright Law and except by reviewers for the public press), without written permission from the publishers.

Yale University Press books may be purchased in quantity for educational, business, or promotional use. For information, please e-mail sales.press@yale.edu (U.S. office) or sales@yaleup.co.uk (U.K. office).

Set in Janson type by Integrated Publishing Solutions,

Grand Rapids, Michigan.

Printed in the United States of America.

Library of Congress Control Number: 2018953596

ISBN 978-0-300-240 13-9 (hardcover : alk. paper)

A catalogue record for this book is available from the British Library.

This paper meets the requirements of ANSI / NISO Z $39 \cdot 48$ - I992

(Permanence of Paper).

I0 $98 \begin{array}{lllllll} & 6 & 5 & 4 & 32 & 2 & \text { I }\end{array}$ 